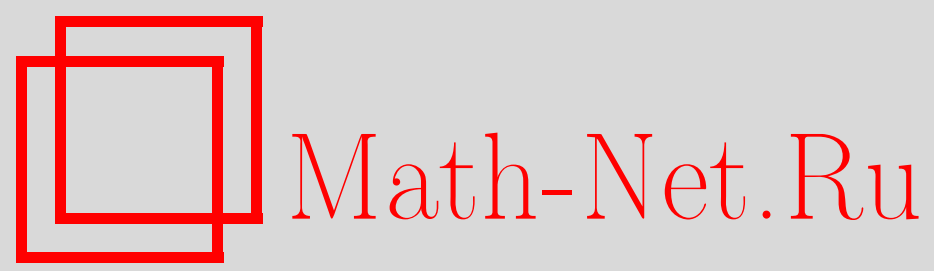

Н. Н. Фотиева, Т. Г. Саммаль, Математическое моделирование взаимодействия бетонной обделки канализационного тоннеля, подвергающейся газовой коррозии, с массивом грунта, Вестн. Сам. гос. техн. ун-та. Сер. Физ.-мат. науки, 1998, выпуск 6, 149

DOI: https://doi.org/10.14498/vsgtu23

Использование Общероссийского математического портала Math-Net.Ru подразумевает, что вы прочитали и согласны с пользовательским соглашением

http://www. mathnet.ru/rus/agreement

Параметры загрузки:

IP : 54.84 .234 .179

26 апреля 2023 г., 17:00:17 


\section{МАТЕМАТИЧЕСКОЕ МОДЕЛИРОВАНИЕ ВЗАИМОДЕЙСТВИЯ БЕТОННОЙ ОБДЕЛКИ КАНАЛИЗАЦИОННОГО ТОННЕЛЯ, ПОДВЕРГАЮЩЕЙСЯ ГАЗОВОЙ КОРРОЗИИ, С МАССИВОМ ГРУНТА}

Решена задача о напряженно-деформированном состоянии бетонной обделки тоннеля с учетом газовой коррозии. Приведены примеры численного решения задачи.

Предлагаемая математическая модель предназначена для прогноза снижения несущей способности бетонных обделок канализационных коллекторных тоннелей в процессе их эксплуатации, обусловленной локальным уменьшением толщины обделки в сводовой части вследствие влияния агрессивной газовой среды выше зеркала сточных вод, которое с течением времени может привести к обрушению тоннеля и прорыву канализационных стоков в окружающую среду. Математическая модель базируется на новом аналитическом решении плоской контактной задачи теории упругости для весомой линейнодеформируемой среды, моделирующей массив грунта, ослабленной круговым отверстием, подкрепленным кольцом переменной толщины, моделирующим обделку тоннеля, подвергающуюся коррозии в сводовой части, при граничных условиях, отражающих действие собственного веса грунта (рассматривается случай заглубленной выработки, когда влиянием дневной поверхности можно пренебречь) или внутреннего напора (в период водосброса в напорном режиме).

Расчетная схема показана на рис.1. Здесь линейно-деформируемая среда $S_{0}$, механические свойства которой характеризуются модулем деформации $E_{0}$ и коэффициентом Пуассона $v_{0}$, моделирует массив грунта. Кольцо $S_{1}$, материал которого имеет деформационные характеристики $E_{1}, v_{1}$, моделирует обделку тоннеля.

Действие собственного веса грунта моделируется наличием в области $S_{0}+S_{1}$ начальных напряжений $\sigma_{x}^{(0)}, \sigma_{y}^{(0)}$, обусловленных гравитационными силами (для простоты удельный вес бетона и удельный вес грунта принимаются одинаковыми). Внутренний контур $L_{0}$ свободен от действия внешних сил, либо (при моделировании работы тоннеля в период водосброса в напорном режиме) нагружен равномерно распределенным давлением $-p$.

Поставленная задача решена с использованием теории аналитических функций комплексного переменного, аппарата конформных отображений, комплексных рядов Лорана и полиномов Фабера. Составлен полный

алгоритм расчета, реализованный в виде компьютерной программы.

Ниже в качестве примера приводятся результаты расчета обделки коллекторного тоннеля на действие внутреннего напора при следующих исходных данных: внешний радиус обделки $R_{0}=1.6$ м, толщина обделки $\Delta=0.2 \mathrm{M}$; деформационные характеристики грунта и материала обделки соответственно: $E_{0}=1400$ МПа, $v_{0}=0.3$, $E_{1}=23000 \mathrm{MПа,} v_{1}=0.2$. Принималось, что в результате газовой коррозии бетона внутренний контур поперечного сечения конструкции в сводовой части, начиная с высоты 2.4 м, приобретает эллиптическую форму; при этом толщина обделки в своде составляет 5 см.

Расчетные эпюры нормальных тангенциальных напряжений $\sigma_{\theta}^{(i n)} / p$ на внешнем и $\sigma_{\theta}^{(e x)} / p$ на внутреннем контурах поперечного сечения обделки приведены соответ-

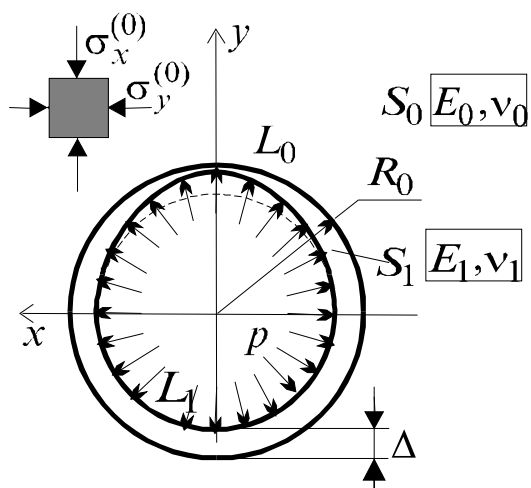

Р и с. 1. Расчетная схема

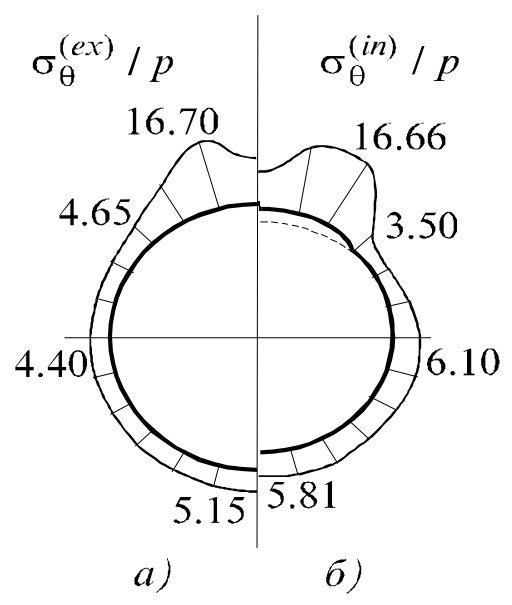

Р и с. 2. Результаты расчета ственно на рис. 2, $a, \sigma$.

Следует отметить, что в начальный период эксплуатации, когда обделка имеет постоянную толщину $\Delta=0.2$ м, соответствующие напряжения составляют: $\sigma_{\theta}^{(i n)} / p=4.87, \sigma_{\theta}^{(e x)} / p=5.64$. 